\title{
Segmentasi Citra Paru Menggunakan Metode $k$-Means Clustering
}

\author{
Atina \\ Universitas PGRI Palembang \\ Email: atina.salsabila@gmail.com
}

Received July 17, 2017; Revised July 21, 2017; Accepted September 15, 2017

\begin{abstract}
Abstrak
Dalam bidang kesehatan, segmentasi biasa digunakan untuk mempermudah tenaga medis untuk menginterpretasikan citra medis pasien khususnya di bidang radiografi. Dengan memanfaatkan intensitas dan nilai piksel citra, segmentasi citra radiografi dengan metode k-means clustering dapat dilakukan. Pada penelitian ini, citra yang digunakan adalah citra paru hasil Computed Radiography (CR). Adapun tujuan dari penelitian ini adalah untuk mengetahui nilai $k$ (jumlah cluster) yang tepat untuk memvisualisasikan citra CR dengan mengabaikan citra jantung yang terbentuk pada citra paru kiri. Jumlah cluster yang terbentuk divisualisasikan dengan jumlah warna yang terbentuk pada citra hasil clustering. Algoritma clustering disusun dengan menggunakan program Matlab 2013a, dengan menguji coba nilai $k=3,4,5, \ldots, 10$. Dari penelitian diperoleh bahwa $k=8$ dapat memvisualisasikan pembentukan warna yang lebih nyata dibanding dengan jumlah cluster yang lain.
\end{abstract}

Kata kunci: citra paru, segmentasi, $k$-means clustering

\section{Lung Image Segmentation Using $k$-Means Clustering}

\begin{abstract}
In the field of health, segmentation is commonly used to facilitate medical personnel to interpret the patient's medical image, especially in the field of radiography. By utilizing the intensity and value of image pixels, radiographic image segmentation by k-means clustering method can be done. In this study, the image used is the Computed Radiography $(C R)$ lung image. The purpose of this study is to determine the exact value of $k$ (cluster number) to visualize CR image by ignoring the image of the heart formed on left lung image. The number of clusters formed is visualized by the number of colors formed on the image of the clustering result. The clustering algorithm is constructed using the Matlab 2013 a program, by testing the values of $k=3,4,5, \ldots, 10$. From the research, it is found that $k=8$ can visualize the formation of color that more real than the number of other clusters.
\end{abstract}

Keywords: lung image, segmentation, $k$-means clustering

DOI : 10.25273/jpfk.v3i2.1475

\section{PENDAHULUAN}

Sejak awal ditemukannya pada tahun 1895 oleh William Rontgen, pemanfaatan sinar- $x$ terus berkembang pesat di berbagai bidang termasuk dalam bidang kesehatan khususnya dunia diagnostik. Pencitraan yang memanfaatkan sinar-x terus berkembang hingga sekarang. Terdapat 2 modalitas utama yang memanfaatkan sinar-x yakni radiografi (menggunakan film screen) dan fluoroscopy (menggunakan penguatan citra sinar-x atau sistem video). Semenjak era tahun 70-an, modalitas baru pencitraan digital mulai dikembangkan yang termasuk didalamnya adalah Computed Radiography

(CR) (Rowlands, Zhao, \& Anthony, 1994).

Teknologi Computed Radiography (CR) merupakan proses perubahan teknologi citra radiografi analog menjadi digitalisasi citra. Pada teknologi citra radiografi analog, citra yang terbentuk akan dicetak dalam bentuk film screen sedangkan pada teknologi CR citra yang terbentuk akan disimpan dalam bentuk file digital sebagai hasil dari akuisisi sinar-x yang melewati objek. Citra radiografi yang terbentuk disimpan dalam bentuk file digital untuk kemudian direpresentasikan oleh tenaga medis (Ahmas, Muhlisin, \& Widiyandari, 2015; Rowlands J. A., 2002). 


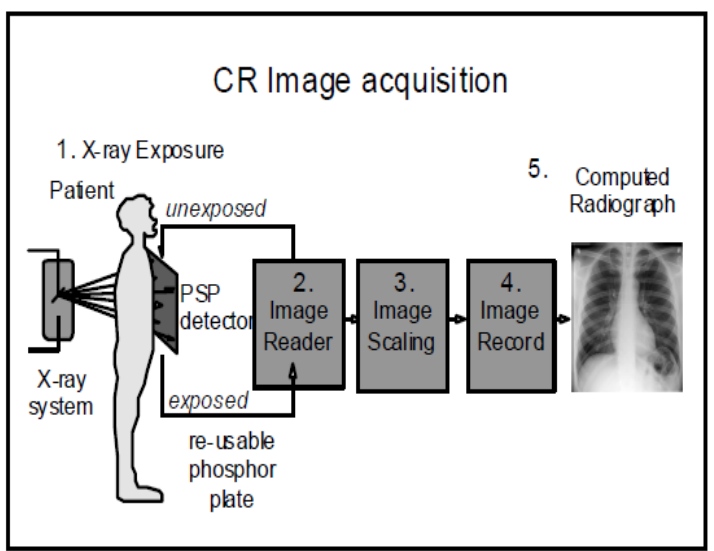

Gambar 1. Proses pengambilan citra CR (Sheibert, 1999).

Gambar 1. menunjukkan proses pengambilan citra pada teknologi CR. Berkas sinar-x yang melewati pasien akan ditangkap oleh imaging plate. Imaging plate adalah komponen CR yang menggantikan fungsi film screen pada radiografi konvensional. Pada imaging plate sinar-x disimpan dalam bentuk photo stimulable phosphor (PSP) untuk kemudian disimpan dalam bentuk data digital. Selanjutnya, secara mekanik imaging plate dipindahkan ke image reader yang berfungsi sebagai pembaca dan pengolah citra. Pada image reader, data yang diperoleh dari imaging plate akan mengalami scanning menggunakan laser sehingga cahaya tampak akan dilepaskan dari plate. Gambaran citra akan ditampilkan di layar monitor.

Sementara itu, imaging plate akan masuk ke bagian data penghapusan (erasure) untuk dibersihkan sehingga dapat digunakan kembali. Image reader dilengkapi dengan image console yaitu monitor yang berfungsi menampilkan citra yang telah dibaca image reader. Image console adalah media berupa komputer khusus untuk medical imaging yang dilengkapi menu penunjang untuk proses pengolahan citra. Menu pada image console menunjang untuk proses editing citra seperti densitas, ketajaman serta kontras citra radiografi. Tahap akhir dari proses pemeriksaan adalah dengan mendistribusikan citra hasil olahan pada image console ke image recorder. Disini dilakukan proses penyimpanan dan output citra berupa media compact disc.

Proses radioterapi diperlukan perencanaan yang tepat agar memperoleh hasil terapi yang maksimal (A'isyah, Adi, \& Anam, 2013). Citra radiografi yang terbentuk umumnya diikuti dengan noise sehingga interpretasi secara manual mungkin akan terkendala. Karenanya diperlukan suatu metode khusus yang dapat membantu tenaga medis untuk menginterpretasikan citra hasil radiografi tersebut. Salah satu metode yang dapat dilakukan adalah dengan metode segmentasi citra. Segmentasi citra merupakan salah satu tahapan dalam pengolahan citra yang penting, terutama dalam dunia medis (Mardhiyah \& Harjoko, 2011). Tujuan yang mendasari segmentasi citra adalah membagibagi citra ke dalam bagian-bagian berbeda, membagi daerah mana yang membutuhkan fokus utama dibandingkan latar belakangnya.

Pada penelitian ini, dilakukan segmentasi citra dengan metode $k$-means clustering. $k$-means adalah metode data mining yang melakukan permodelan tanpa arahan (unsupervised) dengan mengelompokkan data ke dalam beberapa cluster berdasarkan kesamaan karakter yang dimiliki. Secara singkat, algoritma k-means clustering mencari objek $N$, berdasarkan parameter, ke dalam $k$ cluster $(k \leq N)$. Untuk pencitraan medis, $N$ sama dengan jumlah piksel citra $N_{x} \times N_{y}$ (Tatiraju \& Mehta, 2008). Hasil yang diinginkan termasuk centroid setiap cluster dan gabungan dari $N$ objek. Standar cluster $k$ means mencoba untuk meminimalkan harga fungsi. Algoritma $k$-means berfungsi mengelompokkan citra data masukan dalam beberapa kelompok berdasarkan jarak minimum.

Titik - titik dikelompokkan disekitar centroid $\mu_{i} \forall_{i}=1 \ldots k, \quad$ dimana diperoleh dengan meminimalkan objek.

$V=\sum_{i=1}^{k} \sum_{x j \in s_{i}}\left(x_{j}-\mu_{i}\right)^{2}$. 
dengan $k$ adalah cluster $S_{i}, \mathrm{i}=1,2, \ldots, k$ dan $\mu_{i}$ adalah centroid atau titik utama dari semua titik $x_{j} \in S_{i}, V$ adalah jarak centroid ke objek.

Tahapan algoritma k-means clustering sebagai berikut :

1. Menghitung penyebaran intensitas (histogram)

2. Inisialisasi centroid dengan intensitas acak $k$

3. Mengulang langkah sampai label cluster citra tidak berubah lagi

4. Titik cluster berdasarkan atas jarak intensitas dari intensitas centroid

$c^{(i)}=\arg \min \left\|x^{(i)}-\mu_{j}\right\|^{2}$

5. Hitung centroid baru untuk masing-masing cluster.

$$
\mu_{i}=\frac{\sum_{i=1}^{m} 1\left\{c_{i}=j\right] x^{i}}{\sum_{i=1}^{m} 1\left\{c_{i}=j\right\}}
$$

dengan $i$ adalah iterasi melalui semua intensitas, $j$ adalah iterasi melalui semua centroid dan $\mu_{i}$ adalah intensitas centroid (Tatiraju \& Mehta, 2008).

Citra medis hasil CR akan dibagi menjadi beberapa cluster dengan menggunakan algoritma yang disusun menggunakan program Matlab 2013a, dengan algoritma ini proses clustering citra dapat dilakukan secara komputerisasi.

$$
\text { Metode } \quad k \text {-means clustering }
$$

memanfaatkan intensitas/ tingkat keabuan citra, intensitas citra inilah yang mendasari clustering citra. Intensitas yang berbeda akan dikelompokkan dalam cluster yang berbeda pula. Jumlah cluster yang terbentuk pada segmentasi citra dengan $k$-means clustering ditunjukkan dengan nilai $k$. Pada penelitian ini dilakukan clustering dengan variasi nilai $k$, sehingga diperoleh nilai $k$ terbaik yang dapat memvisualisasikan citra hasil CR. Citra hasil clustering ini dapat menjadi langkah awal pembuatan computerized aid diagnose (CAD) citra paru.

\section{METODE}

Penelitian ini menggunakan data sampel sebanyak 50 citra hasil CR yang diperoleh dari rumah sakit yang menggunakan pesawat CR. Adapun perangkat lunak yang digunakan adalah program Matlab 2013a dengan algoritma k-means clustering.

\section{- Preprocessing}

Data sampel yang diperoleh dari RS berupa data visual citra hasil $\mathrm{CR}$ yang disimpan dalam data file *.dcm atau dicom (Digital imaging and Communication in Medicine). Sebelum clustering, citra $\mathrm{CR}$ harus melalui tahap preprocessing meliputi akuisisi citra, equalisasi histogram, dan resize citra. Preprocessing perlu dilakukan sebagai tahap awal pengolahan citra digital agar citra yang digunakan sesuai dengan kriteria yang diinginkan.

Akuisisi citra dilakukan dengan mengkonversi citra asli dari file *.dmc menjadi *.tif. Citra dicom ini perlu diubah dalam bentuk lain yang dapat memberikan kontras yang lebih baik, dalam hal ini peneliti memilih menggunakan *.tif file dalam bentuk grayscale karena *.tif file tidak akan menghilangkan informasi data digital seperti tingkat keabuan citra pada saat pengolahan citra. Citra hasil akuisisi selanjutnya perlu perataan histogram. Histogram adalah diagram yang menggambarkan jumlah piksel untuk setiap derajat keabuan pada suatu citra. Pada matlab telah disediakan fungsi untuk perataan histogram ini yaitu dengan menggunakan fungsi histeq (histogram equalization).

Tahapan berikutnya adalah dan resize citra. Penelitian ini hanya menggunakan daerah paru. Sedangkan citra hasil CR tidak hanya menggambarkan paru tetapi termasuk juga didalamnya tulang, jantung dan daerah mediastinum. Oleh karena itu, perlu dilakukan proses untuk menghilangkan daerah/bagian citra yang tidak diperlukan termasuk label kanan-kiri yang terdapat pada citra. Selain itu, proses dilakukan dengan tujuan untuk menyamakan daerah fokus citra. Besarnya ukuran citra akan menyebabkan lamanya proses segmentasi berlangsung, sehingga perlu dilakukan resize citra agar lebih efektif waktu tentu saja dengan tidak mempengaruhi hasil akhir.

\section{- Segmentasi k-means Clustering}

Proses tahapan segmentasi dengan metode $k$-means clustering disusun dalam algoritma Matlab. Tujuan dari clustering ini adalah membagi citra mejadi beberapa kelompok/cluster sesuai dengan kedekatan intensitas keabuan citra tersebut. Citra yang akan diproses /dikelompokkan hanya daerah 
paru sehingga diperlukan proses awal untuk menghilangkan daerah sekitar paru. Citra yang diperoleh kemudian akan terdiri atas bagian objek dan bagian latar belakang (Watiningsih, 2012).

Pada Matlab tersedia algoritma yang dapat mendeteksi bagian tertentu saja pada citra.Peneliti menggunakan algoritma ini untuk mendeteksi bagian paru dan menghilangkan daerah disekitarnya.Citra hasil preprocessing diubah menjadi citra biner berdasarkan ambang batas tingkat keabuannya yaitu 256 piksel.Sehingga untuk menjadikan citra biner diperlukan 128 piksel.Setelah citra biner diperoleh dilakukan penghapusan daerah sekitar paru dengan segmentasi deteksi posisi paru pada citra awal menggunakan deteksi batas objek.
Clustering dilakukan pada citra hasil preprocessing. Proses clustering akan dimulai dengan menghitung nilai centroid secara acak, kemudian menghitung jarak minimum antar centroid dengan menggunakan Euclidean distance. Euclidean distance adalah metode pengukuran jarak minimum antar centroid dalam citra yang akan dikelompokkan/cluster. Selanjutnya, piksel akan dikelompokkan berdasarkan jarak minimum tersebut hingga membentuk cluster. Jika masih ada cluster yang berpindah, maka akan dihitung kembali jarak minimum ke centroid. Namun jika tidak ada cluster yang berpindah maka proses clustering selesai. Clustering dilakukan dengan variasi jumlah cluster $(k)$ yaitu $\mathrm{k}=3,4,5, \ldots$, 10. Dari hasil clustering ini akan dilihat nilai $k$ yang memberikan hasil terbaik (yang memberikan visualisasi citra cluster terbaik).

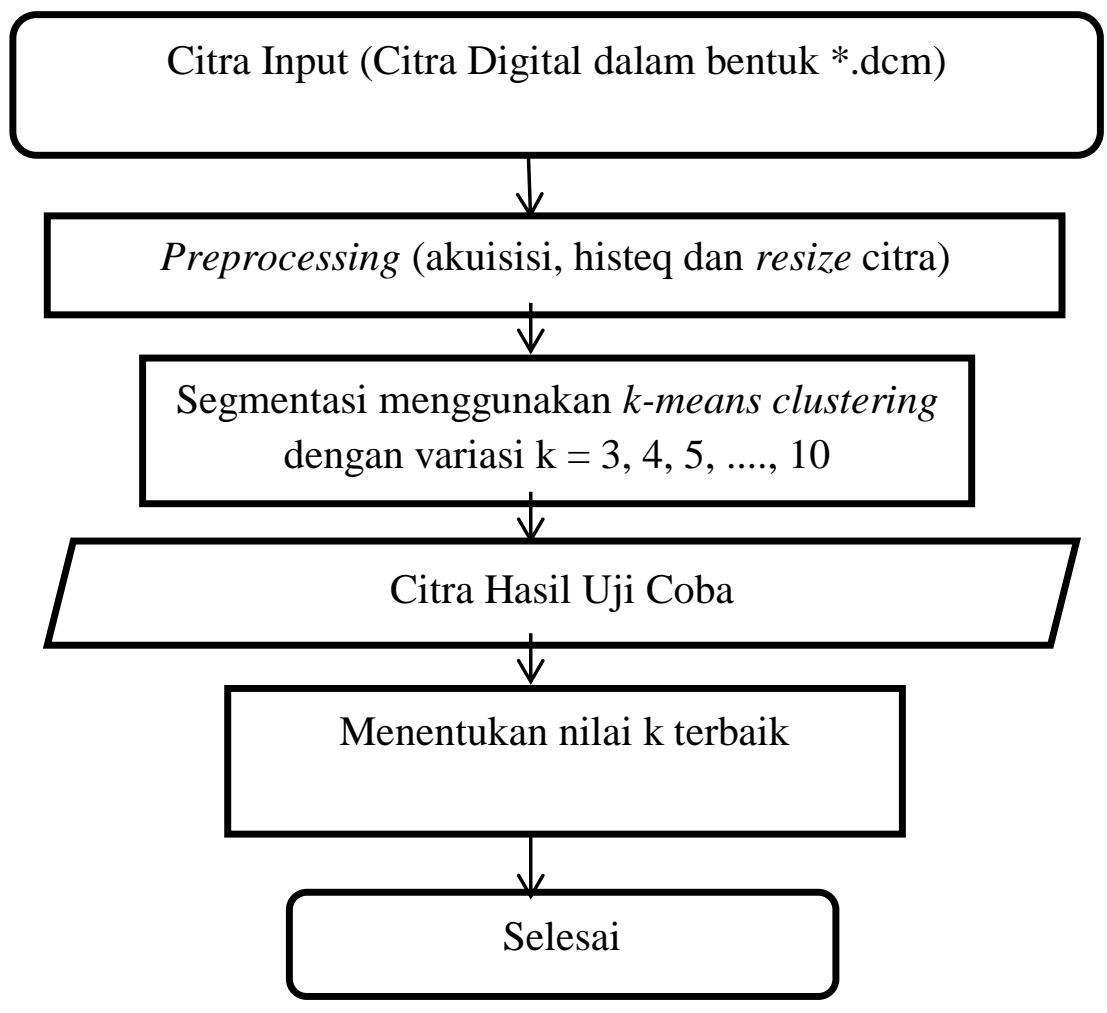

Gambar 2. Diagram alir penelitian

Metode k-means clustering memanfaatkan intensitas/ tingkat keabuan citra, intensitas citra inilah yang mendasari clustering citra. Intensitas yang berbeda akan dikelompokkan dalam cluster yang berbeda pula. Cluster yang terbentuk akan diwakili oleh warna tertentu sehingga masing-masing cluster akan dapat tervisualisasi.
Data hasil penelitian berupa citra hasil clustering dengan jumlah cluster yang berbeda-beda sesuai nilai $k$ yang diinput. Dari data citra ini, akan dilihat secara manual nilai $k$ yang mampu memberikan visualisasi citra yang paling baik yaitu yang mampu memberikan pembagian cluster dengan warna yang jelas. 


\section{HASIL DAN PEMBAHASAN}

Citra paru hasil $\mathrm{CR}$ memiliki intensitas keabuan yang sangat dekat, karenanya secara visual sering kali terjadi perbedaan analisis.Untuk itulah diperlukan suatu algoritma yang dapat melakukan analisis secara komputerisasi. Algoritma disusun menggunakan MatLab 2013a dengan metode k-mean clustering. Agar proses segmentasi dapat berjalan optimal perlu dilakukan preprocessing yang meliputi akuisisi citra, equalisasi histogram, cropping dan resize citra. Akuisisi citra dilakukan dengan mengubah citra dari bentuk *.dcm menjadi *.tif file.Citra hasil akuisisi ini kemudian dilakukan perataan histogram(equalisasi histogram).
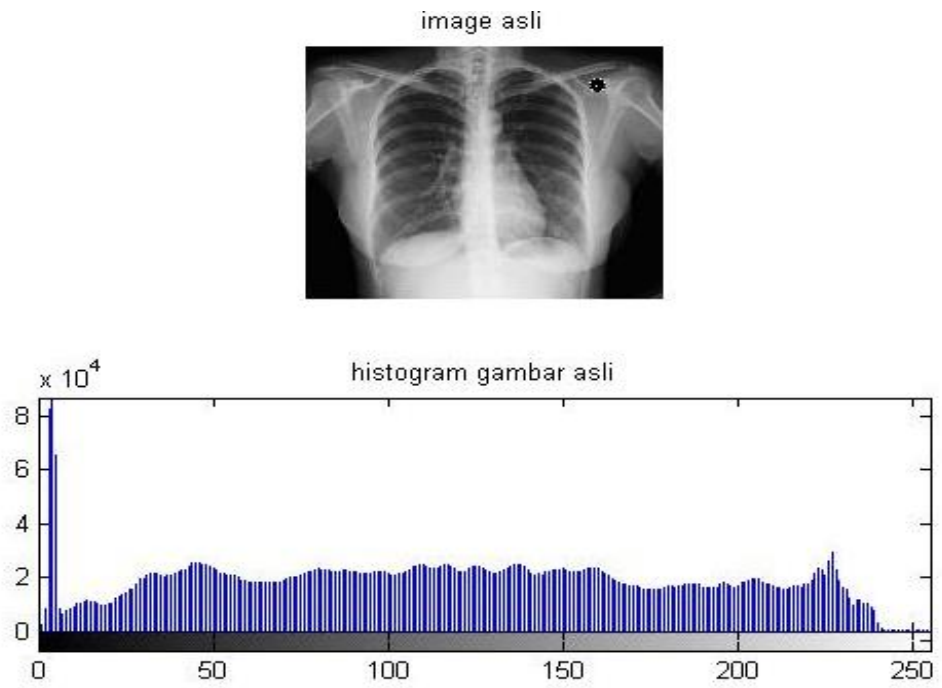

Gambar 3. Contoh citra asli dan histogram citra

image equalisasi
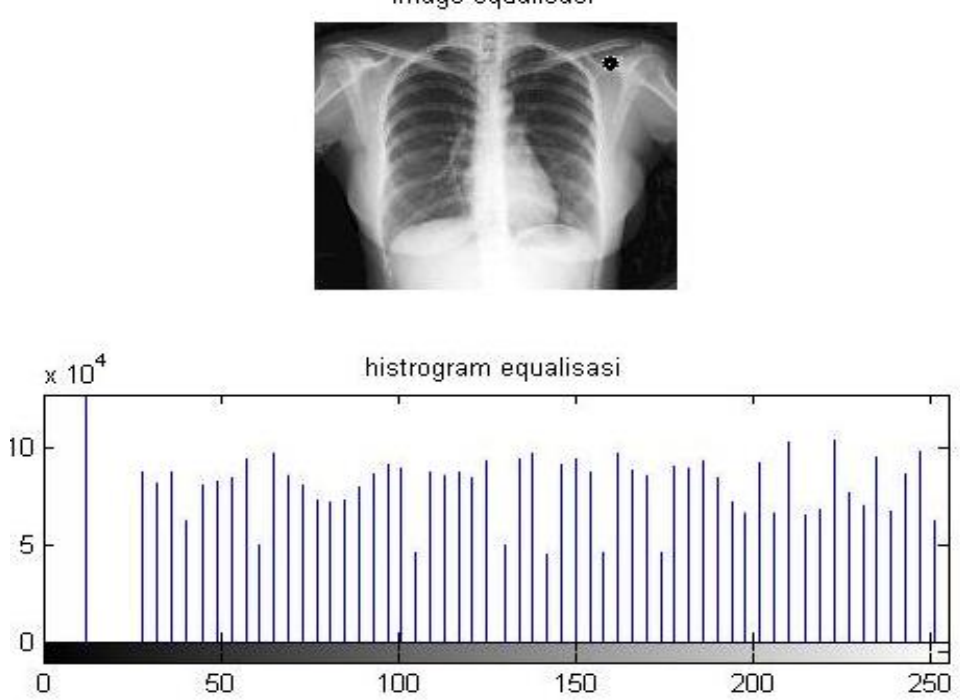

Gambar 4. Contoh citra dan histogram hasil equalisasi 
Jurnal Pendidikan Fisika dan Keilmuan (JPFK) Vol 3 No 2 September 2017, hal 57 -65 Avaliable online at: http://e-journal.unipma.ac.id/index.php/JPFK Print ISSN: 2442-8868, Online ISSN: 2442-904x

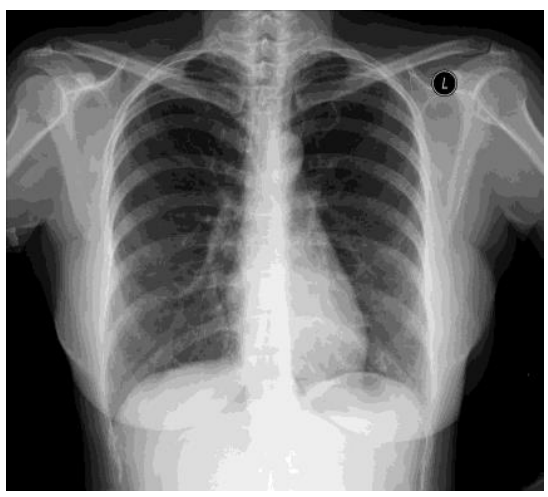

(a)

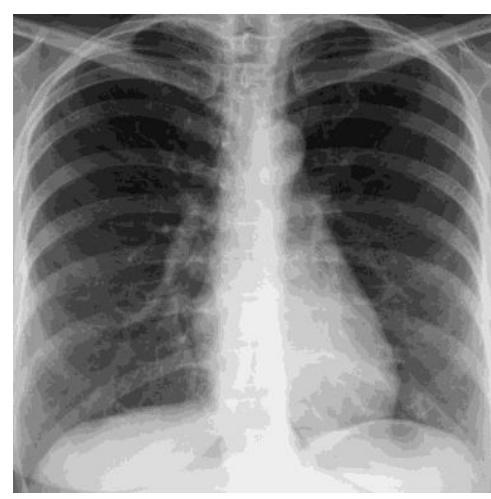

(b)

Gambar 5. Croppingdan resize citra (a) Contoh citra asli hasil equalisasi,

(b) Contoh hasil cropping dan resize citra

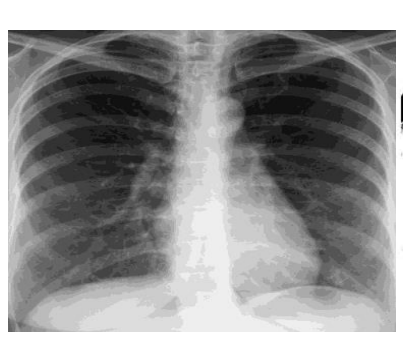

(a)

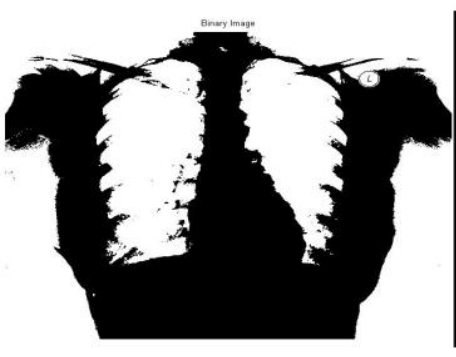

(b)

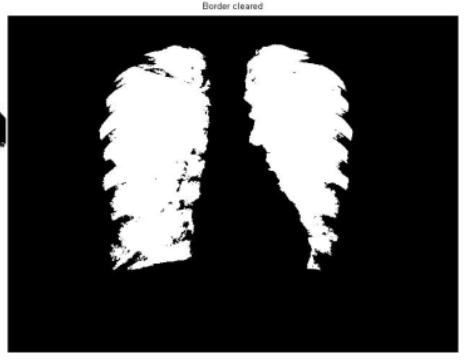

(c)

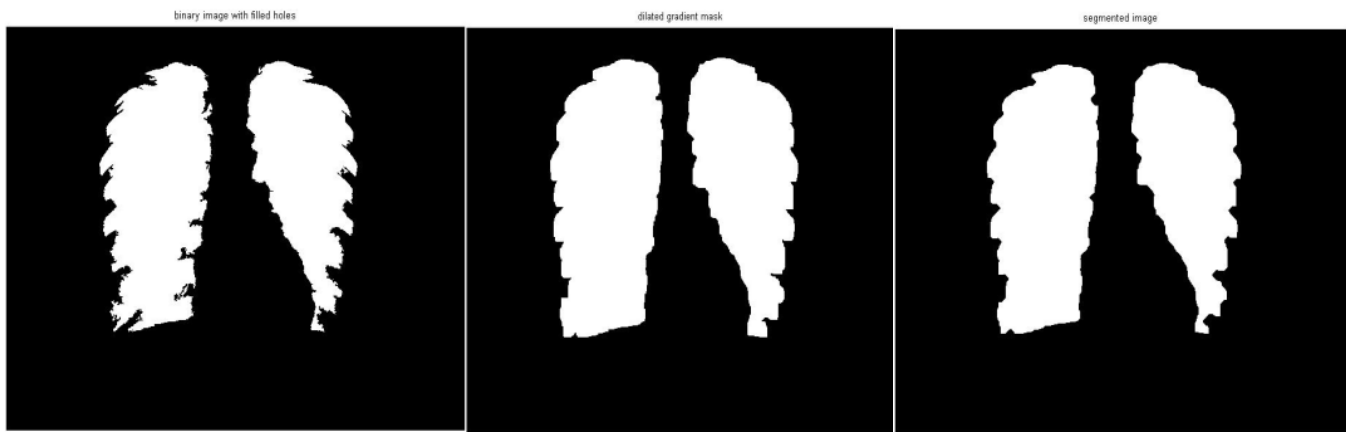

(d)

(e)

(f)

Gambar 6. Proses segmentasi paru (a) citra asli, (b) citra biner, (c) cleared border, (d) citra biner dengan pengisian daerah dalam, (e) dilated gradient mask, (f) citra segmentasi 

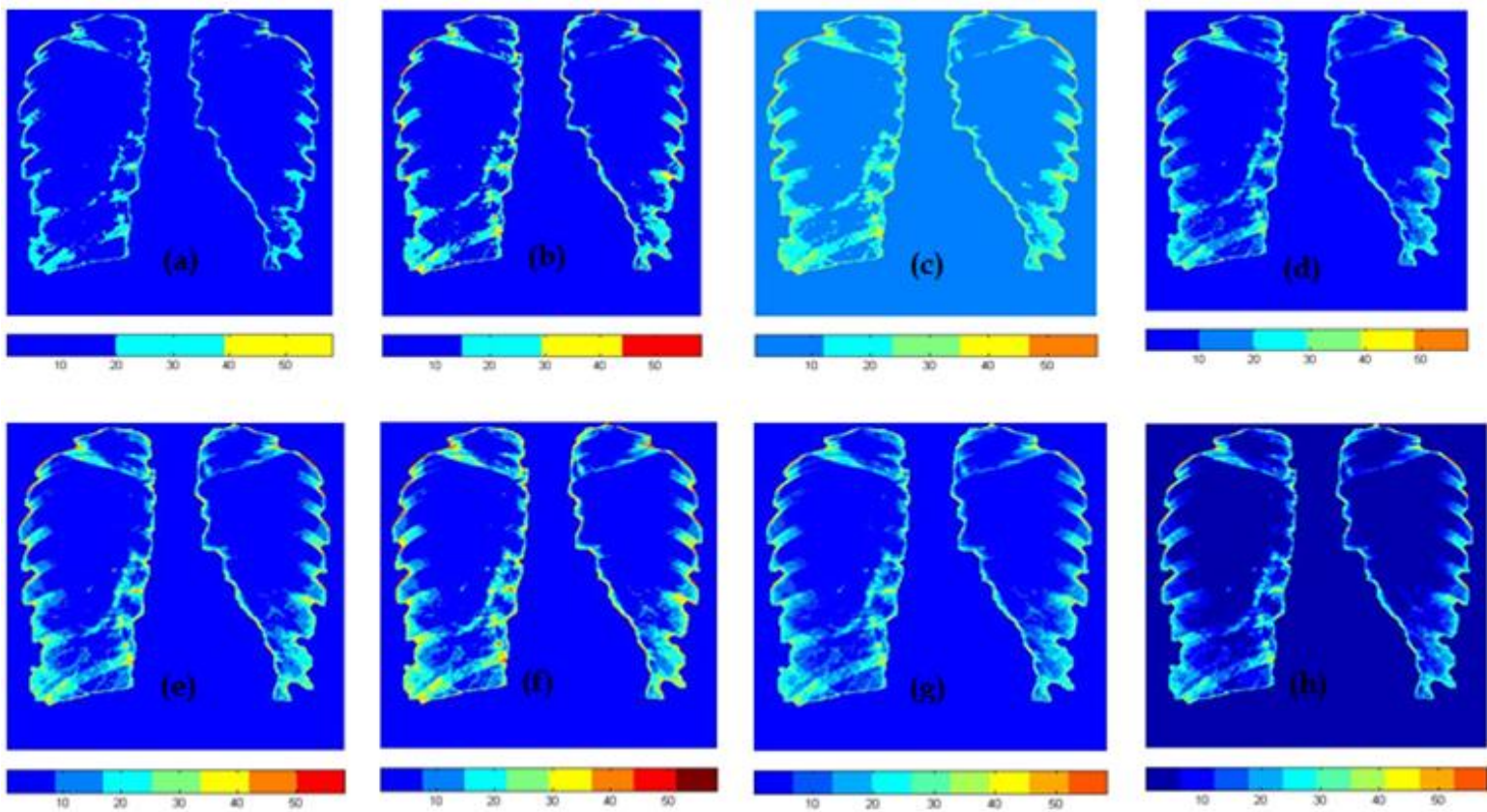

Gambar 7. Contoh citra hasil clustering dengan metode $k$-means clustering dengan (a). $k=3$, (b). $k=$ 4, (c). $k=5$, (d). $k=6$, (e). $k=7$, (f). $k=8$, (g). $k=9$, (h). $k=1$

Penelitian ini menggunakan citra Computed Radiography (CR) sebagai bahan penelitian. Kesalahan visual dalam interpretasi citra dapat disebabkan karena tingkat keabuan yang dimiliki citra sangat dekat, sehingga diperlukan pembacaan tingkat keabuan yang terkomputerisasi agar pembacaan tingkat keabuan semakin teliti. Ketelitian sistem komputerisasi dalam pembacaan tingkat keabuan citra diharapkan dapat lebih akurat jika dibandingkan dengan pembacaan secara manual. Metode k-means clustering digunakan untuk mengelompokkan citra berdasarkan intensitas keabuan yang dimiliki sehingga interpretasi citra diharapkan dapat lebih mudah dilakukan. Perbedaan intensitas citra akan ditampilkan dalam bentuk warna yang jelas.

Computed radiography (CR) adalah proses digitalisasi gambar yang menggunakan Photostimulable Plate untuk akuisisi data gambar. Pada dasarnya CR sama dengan radiografi konvensional, hanya saja penerima gambar yang digunakan adalah Photostimulable Phosphor Plate sebagai Imaging Plate (IP) yang pertama kali diperkenalkan pada tahun 1981 di Brussel. Bila sinar-X diinteraksikan dengan bahan dapat diteruskan, dihamburkan dan diserap. Banyaknya foton sinar-X yang diteruskan dan dihamburkan akan berpengaruh pada kualitas radiograf yang dihasilkan, sedangkan foton sinar-X yang diserap hanya akan berpengaruh pada dosis radiasi yang diterima pasien (Fahmi, Firdausi, \& Budi, 2008).

Perbedaaan tingkat keabuan/intensitas pada citra hasil radiografi disebabkan kepadatan/massa objek yang dilewati sinar-x berbeda-beda. Nodul atau infiltrat yang dapat diartikan sebagai tanda ketidaknormalan pada jaringan (dalam hal ini paru) memiliki massa yang lebih tinggi dibanding jaringan paru normal. Sehingga daerah nodul menyerap sinar-x lebih banyak. Oleh sebab itu, daerah nodul memiliki intensitas yang lebih tinggi dibanding daerah normal.

Tingkat keabuan/intensitas citra dapat diukur dengan mengolah citra digital secara tepat, dalam hal ini adalah citra hasil CR paru pasien dewasa. Agar citra sesuai dengan kebutuhan maka pada pengolahan citra digital umumnya diperlukan tahap preprocessing.Tahapan ini bergantung sesuai kebutuhan pengguna. Pada penelitian ini dilakukan preprocessing dengan akuisisi citra, equalisasi histogram, cropping dan resize citra.

Citra CR dari rumah sakit disimpan dalam bentuk *.dem diakuisisi dengan mengubah dan menyimpan dalam file *.tif.Citra hasil akuisisi memerlukan perataan histogram. Equalisasi/perataan histogram 
dilakukan agar menghasilkan citra dengan kontras yang lebih baik dari sebelumnya.Gambar 3. dan 4. adalah contoh salah satu citra dan histogramnya yang digunakan dalam penelitian.Gambar 3. menunjukkan histogram citra asli dan Gambar 4. menunjukkan histogram citra hasil equalisasi.Terlihat bahwa citra hasil equalisasi memiliki kontras yang lebih baik dari sebelumnya dengan histogram citra menjadi lebih merata terdistribusi pada rentang yang lebih lebar.Sumbu- $x$ (absis) pada histogram menujukkan tingkat warna dan sumbu-y (ordinat) menunjukkan frekuensi kemunculan titik/nilai piksel citra (Prasetyo, 2011).

Gambar 3. adalah citra asli dan histogramnya. Pada tingkat warna diwakili oleh angka 0 untuk hitam gelap dan angka 1 untuk putih sempurna. Contoh citra diatas menunjukkan jumlah piksel cenderung berkumpul di daerah gelap dengan kerapatan tinggi untuk setiap tingkat keabuan dan mengalami piksel tertinggi pada daerah gelap. Fungsi histeq (histogram equalization) pada matlab berfungsi mengubah nilai sebaran piksel pada setiap tingkat keabuan. Hal ini dapat dilihat pada Gambar 4., rentang warna/tingkat keabuan daerah setelah mengalami perataan histogram menjadi lebih lebar dengan nilai piksel relatif merata. Selanjutnya agar proses komputerisasi berjalan efektif, bagian citra yang tidak digunakan dapat dihilangkan dan memperkecil ukuran citra menjadi $1750 \times 1750$ piksel. Pada Matlab telah disediakan fungsi untuk memotongdan resize citra. Sehingga proses ini dapat berjalan secara otomatis.

Sebelum melakukan proses clustering, diperlukan proses segmentasi citra dengan tujuan memfokuskan objek clustering pada daerah paru saja. Langkah ini dapat dilakukan dengan memodifikasi algoritma deteksi cell yang telah disediakan di Matlab.Tahap ini dilakukan hingga terbentuk citra hasil segmentasi yang siap dikelompokkan/ clustering. Penjelasan proses segmentasi ini ditunjukkan Gambar 6. Proses pertama adalah binerisasi citra, citra yang akan disegmentasi dibedakan menjadi citra hitam putih. Nilai batas tingkat keabuan citra adalah 256 sehingga untuk membentuk citra biner digunakan nilai batas 128 . Proses selanjutnya adalah menghilangkan bagian tulang dengan fungsi cleared border pada matlab, mengisi daerah bagian dalam dari citra biner dan menghaluskan citra dengan dilated gradient mask hingga diperoleh citra hasil segmentasi.

Telah diuji coba clustering citra normal dengan variasi jumlah cluster $(k)$ antara $3-10$ cluster. Contoh citra hasil clustering citra ditunjukkan pada Gambar 7. Cluster yang terbentuk diwakilkan dengan pembentukan warna sesuai jumlah cluster $(k)$ yang ditentukan. Berdasarkan gambar dapat dilihat bahwa saat $k=3,4,5,6,7$ terjadi peningkatan kualitas clustering secara perlahan. Pembentukan warna dapat dilihat dengan batas yang semakin jelas seiring kenaikan bertambahnya jumlah cluster. Sampai pada $k=$ 8 dapat diperhatikan bahwa ternyata citra hasil clustering dapat menayangkan/ memvisualisasikan pembentukan warna yang lebih nyata dibanding dengan jumlah cluster yang lebih kecil.

Saat $k$ dinaikkan menjadi 9 dan 10 , citra hasil clustering cenderung menampilkan warna yang tumpang tindih satu sama lain. Sehingga kelompok warna yang terbentuk menjadi tidak jelas. Hal ini disebabkan begitu dekatnya intensitas keabuan citra sehingga citra cenderung tidak dapat dibagi menjadi 9 atau 10 kelompok warna. Karena itulah clustering dengan $k=8$ dinilai sebagai clustering yang terbaik. Hasil clustering diatas merupakan hasil visual yang dalam interpretasinya masih tergantung pada pembaca.

\section{KESIMPULAN}

Segmentasi dengan metode $k$-means clustering menunjukkan hasil terbaik pada jumlah cluster 8 karena pada $k=8$ citra hasil clustering menunjukkan penayangan batas warna yang jelas. Citra hasil clustering ini dapat dijadikan data awal Computerized Aid Diagnose $(C A D)$ citra paru hasil radiografi sehingga jenis penyakit/ketidaknormalan dapat dideteksi secara komputerisasi.

\section{DAFTAR PUSTAKA}

Ahmas, S., Muhlisin, Z., \& Widiyandari, H. (2015). Studi Pengaruh Ukuran Pixel Imaging Plate Terhadap Kualitas Citra Radiografi. BERKALA FISIKA, 18(3), 89-94.

A'isyah, S., Adi, K., \& Anam, C. (2013). Pembuatan Program Rekonstruksi Kontur Citra 3D pada Organ 


\begin{abstract}
Menggunakan Matlab 2008a. YOUNGSTER PHYSICS JOURNAL, $1(5), 213-220$.
\end{abstract}

Fahmi, A., Firdausi, K. S., \& Budi, W. S. (2008). Pengaruh Faktor Eksposi pada Pemeriksaan Abdomen Terhadap Kualitas Radiograf dan Paparan Radiasi Menggunakan Computed Radiography. BERKALA FISIKA, 109118.

Justino, H. (2006). The ALARA Concept in Pediatric Cardiac Catheterization: Techniques and Tactics for Imaging Radiation Dose. PEDIATR RADIOL, $36,146-153$.

Mardhiyah, A., \& Harjoko, A. (2011). Metode Segmentasi Paru-paru dan Jantung pada Citra X-ray Thorax. IJEIS, 1(2), 35-44.

Prasetyo, E. (2011). Pengolahan Citra Digital dan Aplikasinya Menggunakan Matlab. Gresik: Andi Yogyakarta.

Rowlands, J. A. (2002). The physics of computed radiography. Physics in medicine and biology,.

Sheibert, J. A. (1999). AAPM.

Tatiraju, S., \& Mehta, A. (2008). Image Segmentation using k-means clustering, EM and Normalized Cuts. Department of EECS, University of California , 1-7.

Watiningsih, T. (2012). Pengolahan Citra Foto Sinar-X Untuk Mendeteksi Kelainan Paru. TEODOLITA, 13(1) , 14-30. 